\title{
PENINGKATAN KAPASITAS PRODUKSI LINI PRODUKSI ED FRAME UNTUK MEMENUHI PERMINTAAN PASAR \\ (Studi Kasus: PT. TMMIN)
}

\author{
Muhammad Kholil dan Mochamad Fadly Rafsanjani \\ Program Studi Teknik Industri Universitas Mercu Buana Jakarta \\ e-mail: mochamadfadly.rafsanjani@yahoo.com; m.kholil2009@gmail.com
}

\begin{abstract}
ABSTRAK
PT. TMMIN adalah perusahaan manufaktur Toyota yang memproduksi berbagai macam model kendaraan roda empat yang berada di Indonesia. Proses ED Frame merupakan salah satu proses yang ada dalam serangkaian proses pembuatan sebuah mobil di PT. TMMIN. Pada saat perencanaan kenaikan jumlah permintaan produksi dari pasar dari 160.000 unit/tahun menjadi 250.000 unit/tahun, kondisi yang ada kapasitas pada saat ini masih belum memenuhi ketentuan untuk dapat memenuhi permintaan pasar yang meningkat. Setelah dilakukan pendataan mengenai kapasitas mesin-mesin yang ada di lini produksi ED Frame, ditemukan 3 mesin yang kapasitasnya belum memenuhi ketentuan untuk dapat memenuhi permintaan pasar, diantaraya adalah OHC, ED Tank, dan Oven. Oleh karena itu, dilakukan suatu analisis lebih dalam dengan metode 6 langkah Kaizen fokus pada 3 mesin yang ada pada lini produksi ED Frame tersebut, serta melakukan perbaikan terhadap kapasitas mesin dengan target dapat memenuhi kebutuhan jumlah produksi sesuai dengan permintaan pasar. Setelah analisis dan perbaikan ini dilakukan, terlihat hasil perubahan kapasitas dari OHC, ED Tank, dan Oven yang dicapai dapat memenuhi target yang ditentukan sehingga lini produksi ED Frame siap untuk memenuhi permintaan pasar.
\end{abstract}

Kata Kunci: Kenaikan Kapasitas OHC, ED Tank, Oven, Takt Time.

\section{ABSTRACT}

PT. PT.TMMIN is a manufacturing company Toyota which manufactures various models of four-wheeled vehicles that are in Indonesia. Frame ED process is the one of the processes that exists in the process of making a series of cars in PT. TMMIN. At the time of planning the increase in the number of requests from the market production from 160,000 unit/year to 250,000 unit/year, capacity on current condition that there is still not meet the requirements to be able to meet the increasing market demand. After collecting data regarding the capacity of existing machines in the production line ED Frame, we found three machine that their capacity can not meet the requirements to meet market demand, that are OHC, ED Tank, and Oven. Therefore, do a deeper analysis with 6 steps of Kaizen methods focuses on three existing machines on the production line of the Frame ED, as well as make improvements to the machine capacity to meet the needs of the target amount of production in accordance with market demand. After analysis and improvement realization, visible result of the capacity changes OHC, ED Tank, and Oven achieved to meet the targets set so that the ED Frame production line ready to meet the market demand.

Keywords: Increase Capacity, OHC, ED Tank, Oven, Takt Time.

\section{PENDAHULUAN}

Toyota merupakan pabrikan mobil terbesar di Jepang. Pabrikan mobil terbesar ketiga di dunia dalam unit sales dan net sales ini menghasilkan 5,5 juta unit mobil di seluruh dunia. Jika dihitung, angka ini ekuivalen dengan memproduksi 1 unit mobil dalam 6 detik. Diantara banyak proses yang ada dalam pembuatan sebuah mobil Toyota, antara lain Stamping, Welding, Machining, Painting, dan Assembling. Proses penting terkait dengan penambahan nilai estetika dan perlindungan dari korosi terhadap unit mobil adalah proses painting. Ada dua item penting yang harus dilakukan proses painting adalah Body dan Frame. Proses painting terhadap frame dilakkan dengan menggunakan ED (Electro Deposition). Proses ED Frame diawali dengan proses pretreatment untuk membersihkan permukaan yang akan dilapisi dari berbagai minyak yang menempel, serta pelapisan anti karat. Dilanjut dengan proses ED painting dengan warna hitam dan langsung dimasukkan ke dalam oven untuk mengeringkan cat yang sudah menempel di permukaan pelapisan. Proses ED Frame merupakan proses Common antara plant-1 dan 
plant-2, artinya proses ED Paint dilalui oleh semua model yang di produksi di Toyota Karawang Plant.

\section{Teori Kapasitas}

\section{TINJAUAN PUSTAKA}

Perencanaan kapasitas dapat dilihat dari tiga horizon waktu. Pada Tabel 1 terlihat bahwa kapasitas jangka panjang (lebih dari 1 tahun) merupakan sebuah fungsi penambahan fasilitas dan peralatan yang memiliki lead time panjang. Pada jangka menengah (3 hingga 18 bulan) dapat ditambah peralatan, karyawan, dan jumlah shift, dapat dilakukan subkontrak dan dapat juga menggunakan persediaan. Hal ini merupakan tugas perencanaan keseluruhan. Dalam jangka pendek (biasanya hingga 3 bulan) perhatian utama terletak pada penjadwalan tugas dan karyawan, dan pengalokasian mesin [1].

Tabel 1. Jenis Perencanaan Menurut Horizon

\begin{tabular}{ll}
\multicolumn{2}{c}{ Waktu [2] } \\
\hline Perencanaan & • Menambah Fasilitas \\
Jangka Panjang & • Menambah peralatan yang \\
& memiliki lead time panjang \\
\hline Perencanaan & • Subkontrak \\
Jangka Menengah & • Menambah Peralatan \\
& • Menambah shift \\
& • Menambah Karyawan \\
& • Membuat atau menggunakan \\
& persediaan \\
\hline Perencanaan & - Mengubah Kapasitas \\
Jangka Pendek & Menjadwalkan tugas \\
& • Penjadwalan karyawan \\
& • Pengalokasian mesin \\
&
\end{tabular}

\section{Perhitungan Jumlah Mesin}

Tentunya untuk dapat memenuhi permintaan kapasitas tertentu harus dapat diketahui mengenai berapa jumlah mesin yang dibutuhkan untuk dapat mencapai suatu kapasitas produksi. Untuk dapat mengetahui berapa jumlah mesin yang harus digunakan dalam suatu kapasitas dapat dihitung dengan rumus berikut [3]:

Jumlah mesin yang dibutuhkan $=$

$$
\frac{\text { WorkLoad }}{\text { Waktu yang tersedia (Takt Time) }}
$$

\section{Penentuan Takt Time per-skid}

PT. Toyota Motor Manufacturing Indonesia memiliki lini produksi dimana dalam satu lini produksi dapat memproduksi lebih dari satu model mobil. Tentunya hal ini membuat adanya perhitungan spesial terhadap Takt Time yang dipakai untuk lini produksi yang ada pada perusahaan tersebut.

Perhitungan Takt Time pada lini produksi ED Frame adalah seperti berikut:

$$
\frac{\text { Menit } / \text { jam }}{\text { Skid/jam }}=\frac{\text { Menit } / \text { jam }}{\left\{\frac{\text { output unit } \frac{A}{j a m}}{\text { jumlah unit } \frac{A}{\text { skid }}}+\frac{\text { output unit } \frac{B}{\text { jam }}}{\text { jumlah unit } \frac{B}{\text { skid }}}\right\}}
$$

\section{Cycle Time}

Waktu yang dibutuhkan seorang operator untuk menyelesaikan 1 siklus pekerjaannya termasuk untuk melakukan kerja manual dan berjalan. Terkadang diartikan sebagai waktu yang dibutuhkan untuk menghasilkan 1 unit produk, dalam hal ini ditentukan dari proses yang paling lama (bottleneck), apakah itu pekerjaan manusia atau mesin.

\section{METODE PENELITIAN}

Kerangka pemikiran pemecahan masalah manajemen material mengacu pada konsep 6 Langkah Kaizen. Kegiatan ini dilakukan melalui pengamatan langsung di PT. TMMIN. Dimulai dengan menentukan latar belakang dan tujuan, kemudian dilanjutkan dengan mengklarifikasi permasalahan berdasarkan data konsumsi material setiap lini produksi. Dari permasalahan yang ada, dilakukan breakdown analysis sehingga diperoleh material dari lini produksi yang memiliki tingkat kapasitas terendah.

\section{Proses Produksi Frame}

1. Lini Produksi Side Rail

Side Rail adalah bagian sisi Frame yang berfungsi sebagai penopang Utama dari semua partisi-partisi kecil yang berfungsi sebagai tempat pemasangan part-part assembly.

2. Lini Produksi Cross Member

Lini Produksi Cross Member membuat semua Cross Member yang memiliki fungsi 
dari masing-masing sebagai tempat instalasi mesin, gandar, suspensi, serta part assembly lainnya.

3. Lini Produksi Finishing

Proses Penggabungan antara Side Rail dengan Cross Member serta partisi-partisi kecil dilakukan di lini produksi finishing sehingga terbentuklah menjadi sebuah frame mobil.

\section{Lini Produksi ED Frame}

Lini Produksi ini bertugas untuk melakukan pelapisan terhadap Frame yang sudah jadi sebagai pelindung dari karat serta menambah nilai estetika suatu frame. Proses yang digunakan adalah melalui proses Electro Plating.

\section{Menemukan potensi perbaikan}

- Analisis terhadap kapasitas mesin

- Menemukan mesin mana yang belum dapat memenuhi target kapasitas

- Menemukan jarak antar target dengan kondisi saat ini

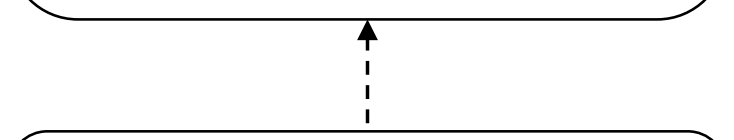

\section{Mengevaluasi metode baru}

- Bandingkan capaian dengan target

- Standardisasi

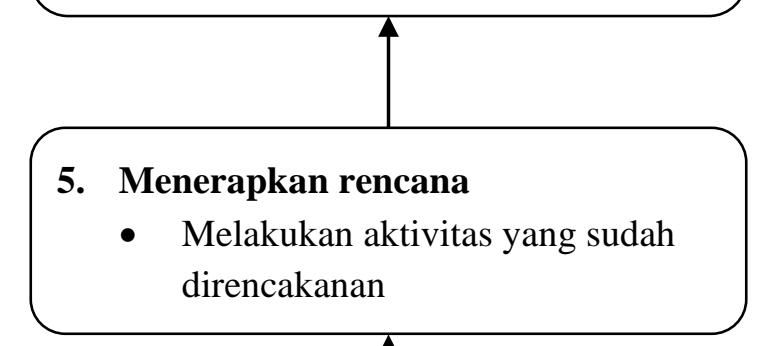

Gambar 1. Enam Langkah Kerangka Kaizen [4]

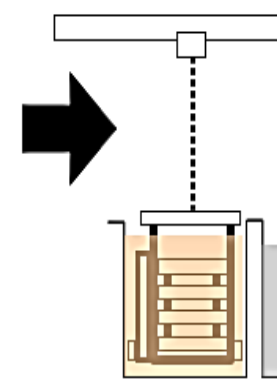

Degreasing

Water

Rinse 1 Conditioning

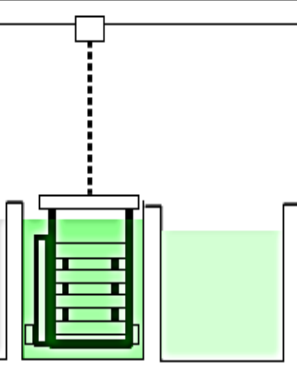

Phosphate

Water

Rinse 2

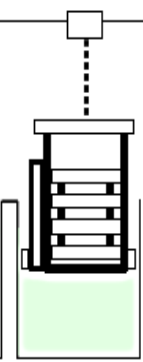

DI Water Rinse

\section{Menganalisis metode yang} digunakan saat ini

- Analisis dari penyebab-penyebab mesin yang belum mencapai target kapasitas

\section{Mencetuskan ide orisinal}

- Membuat beberapa alternatif perbaikan dari akar penyebabyang sudah dianalisis

- Menentukan perbaikan mana yang harus diimplementasikan

\section{Menyusun rencana penerapan}

- Menyusun jadwal aktivitas

Gambar 2. Proses Dipping ED Frame 
Flow Proses Lini Produksi ED Frame

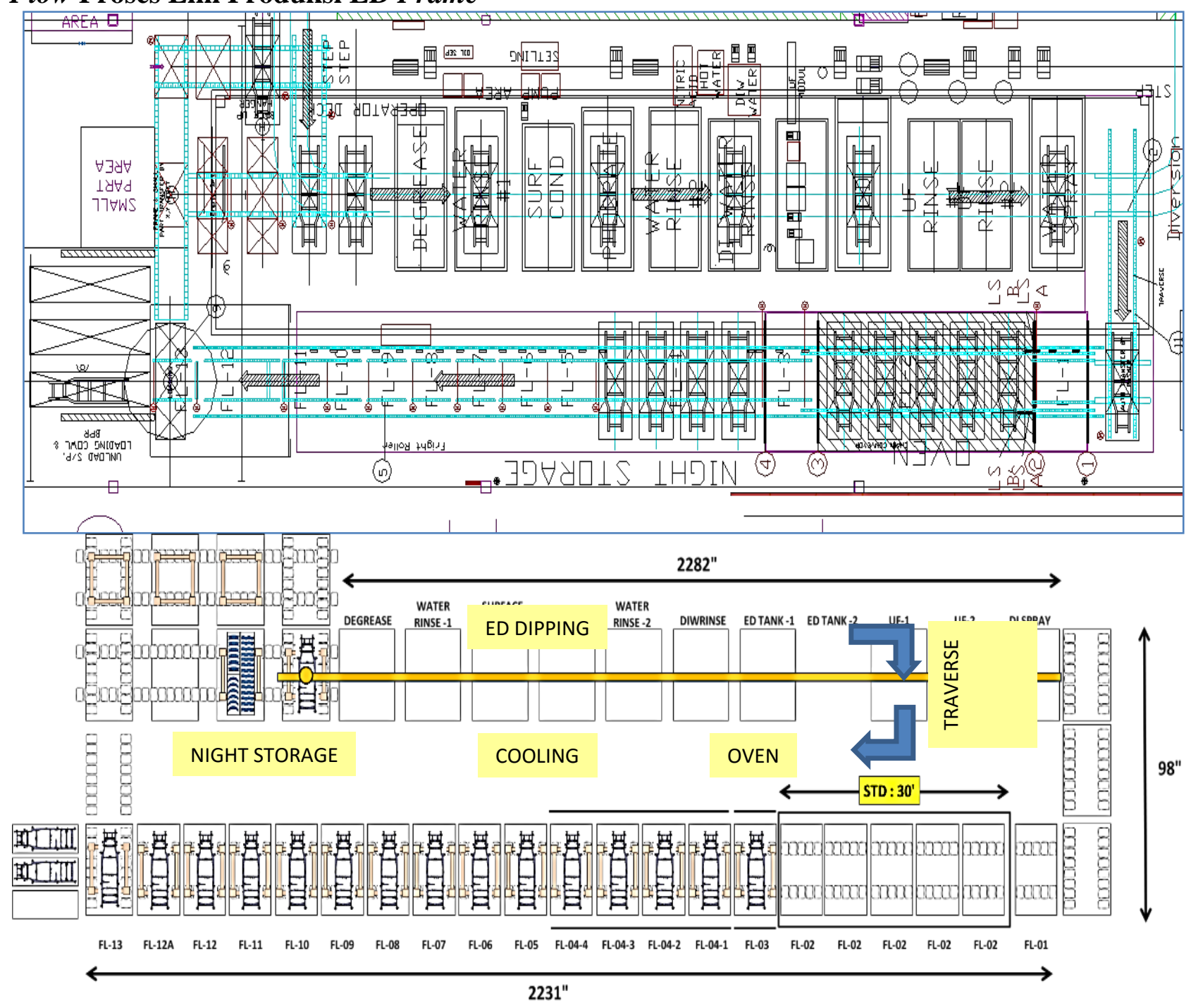

Gambar 3. Layout Lini Produksi ED Frame

Proses ED Frame diawali dengan proses ED Dipping yang didalamnya terbagi menjadi 2 bagian, yaitu Pre-Treatment dan ED process.

\section{Kapasitas Lini Produksi ED Frame Kapasitas Mesin}

\section{OHC (Over Head Conveyor)}

OHC yang ada pada Lini produksi ED Frame berfungsi untuk membawa skid yang berisikan 4 unit Frame untuk setiap proses pencelupan. Kapasitas OHC ED Frame seperti yang ditunjukkan pada Tabel 2.

\section{Dipping}

Proses Pencelupan/dipping yang dilakukan di lini produksi ED Frame ada 10 proses, berikut adalah detail pekerjaan beserta waktu standar yang digunakan oleh setiap proses pencelupannya.

Tabel 2. Pekerjaan pada OHC

\begin{tabular}{ccccc}
\hline No. & $\begin{array}{c}\text { Mesin } \\
\text { (Proses) }\end{array}$ & Jumlah & $\begin{array}{c}\text { Waktu } \\
\text { Siklus/ } \\
\text { skid }\end{array}$ & $\begin{array}{c}\text { Kapasitas } \\
\text { Mesin } \\
\text { Saat Ini }\end{array}$ \\
\hline 1 & Dipping & 8 & $32,8 \mathrm{~min}$ & $4,1 \mathrm{~min}$ \\
2 & Hook-Unhook & 8 & $5,2 \mathrm{~min}$ & $0,65 \mathrm{~min}$ \\
3 & Home Post & 8 & $10,4 \mathrm{~min}$ & $1,3 \mathrm{~min}$ \\
\hline & TOTAL & & $48,4 \mathrm{~min}$ & $\begin{array}{c}6,05 \\
\text { min/skid }\end{array}$ \\
\hline
\end{tabular}

Dari semua data waktu siklus di setiap proses pencelupan, maka kita dapat merangkum bahwa kapasitas dari masing-masing proses pencelupan adalah sebagai berikut: 
Tabel 3. Rangkuman Kapasitas Proses Dipping

\begin{tabular}{|c|c|c|c|c|}
\hline No. & Mesin (Proses) & Jumlah & $\begin{array}{c}\text { Waktu } \\
\text { Siklus/skid }\end{array}$ & $\begin{array}{c}\text { Kapasitas } \\
\text { Mesin Saat } \\
\text { Ini }\end{array}$ \\
\hline 1 & Degreasing & 1 & $4,15 \min$ & $4,15 \min$ \\
\hline 2 & Water Rinse \#1 & 1 & 2,47 min & 2,47 min \\
\hline 3 & $\begin{array}{l}\text { Surface } \\
\text { Condition }\end{array}$ & 1 & 2,22 min & 2,22 min \\
\hline 4 & Phospate & 1 & $3,88 \mathrm{~min}$ & $3,88 \mathrm{~min}$ \\
\hline 5 & Water Rinse \#2 & 1 & $2,47 \min$ & $2,47 \min$ \\
\hline 6 & DI Water Rinse & 1 & $3,10 \mathrm{~min}$ & $3,10 \mathrm{~min}$ \\
\hline 7 & ED Tank & 1 & $6,06 \mathrm{~min}$ & $6,06 \mathrm{~min}$ \\
\hline 8 & Ultra Filter \#1 & 1 & $2,18 \min$ & $2,18 \min$ \\
\hline 9 & Ultra Filter \#2 & 1 & $2,40 \min$ & $2,40 \min$ \\
\hline 10 & DI Water Spray & 1 & $3,9 \mathrm{~min}$ & 3,9 min \\
\hline
\end{tabular}

\section{Traverse}

Traverse merupakan Conveyor yang berfungsi memindahkan skid yang berisikan 4 unit frame dari area dipping ke area oven untuk selanjutnya proses pengeringan yang dilakukan di dalam oven. Berikut data kapasitas Traverse:

Tabel 4. Pekerjaan pada Traverse

\begin{tabular}{ccccc}
\hline No. & $\begin{array}{c}\text { Mesin } \\
\text { (Proses) }\end{array}$ & Jumlah & $\begin{array}{c}\text { Waktu } \\
\text { Siklus/ } \\
\text { skid }\end{array}$ & $\begin{array}{c}\text { Kapasitas } \\
\text { Mesin } \\
\text { Saat Ini }\end{array}$ \\
\hline 1 & $\begin{array}{l}\text { Run Traverse } \\
\text { Door Up } \\
\text { Entrance-1 }\end{array}$ & 1 & $1,0 \mathrm{~min}$ & $1,0 \mathrm{~min}$ \\
3 & Run to FL-1 & 1 & $0,3 \mathrm{~min}$ & $0,3 \mathrm{~min}$ \\
\hline & TOTAL & & $1,76 \mathrm{~min}$ & $0,5 \mathrm{~min}$ \\
\hline
\end{tabular}

\section{FL-1 Conveyor}

Sebelum masuk ke dalam oven, FL-1 ini adalah pemberhentian skid, memiliki 2 pintu untuk dapat menjaga uap panas yang ada di oven dapat keluar dan terjadi penurunan suhu oven yang sudah di standar.

Tabel 5. Pekerjaan pada FL-1

\begin{tabular}{ccccc}
\hline No. & $\begin{array}{c}\text { Mesin } \\
\text { (Proses) }\end{array}$ & Jumlah & $\begin{array}{c}\text { Waktu } \\
\text { Siklus/ } \\
\text { skid }\end{array}$ & $\begin{array}{c}\text { Kapasitas } \\
\text { Mesin } \\
\text { Saat Ini }\end{array}$ \\
\hline 1 & $\begin{array}{c}\text { Door Up } \\
\text { Entrance-2 } \\
2\end{array}$ & 1 & $0,3 \mathrm{~min}$ & $0,3 \mathrm{~min}$ \\
Run to FL-2 & 1 & $0,5 \mathrm{~min}$ & $0,5 \mathrm{~min}$ \\
\hline & TOTAL & & $0,8 \mathrm{~min}$ & $0,8 \mathrm{~min}$ \\
\hline
\end{tabular}

\section{FL-2 Conveyor (Oven)}

Oven yang bertujuan untuk proses pengeringan lapisan cat hasil dari proses ED pada saat dipping. Standar yang ditentukan adalah dengan suhu $215^{\circ} \mathrm{C}$ dengan waktu 30 menit untuk kematangan maksimal.

Tabel 6. Pekerjaan pada FL-2

\begin{tabular}{clccc}
\hline No. & $\begin{array}{c}\text { Mesin } \\
\text { (Proses) }\end{array}$ & Jumlah & $\begin{array}{c}\text { Waktu } \\
\text { Siklus/ } \\
\text { skid }\end{array}$ & $\begin{array}{c}\text { Kapasitas } \\
\text { Mesin } \\
\text { Saat Ini }\end{array}$ \\
\hline 1 & Oven & 5 & $27,5 \mathrm{~min}$ & $5,5 \mathrm{~min}$ \\
2 & $\begin{array}{l}\text { Run Transfer } \\
\text { Door Up } \\
\text { Exit-1 }\end{array}$ & 5 & $2,5 \mathrm{~min}$ & $0,5 \mathrm{~min}$ \\
& TOTAL & & $0,3 \mathrm{~min}$ & $0,06 \mathrm{~min}$ \\
\hline
\end{tabular}

\section{FL-3 Conveyor}

Sama seperti FL-1, FL-3 juga merupakan Floor Conveyor transisi dari oven sebelum keluar kepada Cooling untuk menjaga stabilitas suhu yang ada di dalam oven.

Tabel 7. Pekerjaan pada FL-3

\begin{tabular}{ccccc}
\hline No. & $\begin{array}{c}\text { Mesin } \\
\text { (Proses) }\end{array}$ & Jumlah & $\begin{array}{c}\text { Waktu } \\
\text { Siklus/ } \\
\text { skid }\end{array}$ & $\begin{array}{c}\text { Kapasitas } \\
\text { Mesin } \\
\text { Saat Ini }\end{array}$ \\
\hline 1 & $\begin{array}{l}\text { Door Up } \\
\text { Exit-2 } \\
\text { Run to } \\
\text { Cooling }\end{array}$ & 1 & 0,3 min & 0,3 min \\
2 & 1 & 0,5 min & 0,5 min \\
\hline TOTAL & & 0,8 min & 0,8 min \\
\hline
\end{tabular}

\section{FL-4 Conveyor (Cooling)}

Proses Cooling setelah oven untuk dapat mengembalikan suhu frame yang baru saja keluar dari proses oven karena di proses selanjutnya akan dilakukan proses oleh operator dan segera dikirimkan ke proses assembly. Kapasitasnya adalah sebagai berikut:

Tabel 8. Pekerjaan pada FL-4

\begin{tabular}{ccccc}
\hline No. & $\begin{array}{c}\text { Mesin } \\
\text { (Proses) }\end{array}$ & Jumlah & $\begin{array}{c}\text { Waktu } \\
\text { Siklus/ } \\
\text { skid }\end{array}$ & $\begin{array}{c}\text { Kapasitas } \\
\text { Mesin } \\
\text { Saat Ini }\end{array}$ \\
\hline 1 & Cooling & 4 & $0,4 \mathrm{~min}$ & $0,1 \mathrm{~min}$ \\
2 & Run Transfer & 4 & $1,4 \mathrm{~min}$ & $0,35 \mathrm{~min}$ \\
\hline & TOTAL & & $1,8 \mathrm{~min}$ & $0,45 \mathrm{~min}$ \\
\hline
\end{tabular}




\section{FL5 s/d FL-13 (Night Storage)}

Proses setelah Cooling, frame yang sudah siap untuk dikirimkan ke assembly shop disimpan pada Night Storage Area. Night Storage yang dimiliki oleh Lini produksi ED Frame berjumlah 10 pos. Berikut kapasitasnya:

Tabel 9. Pekerjaan pada FL-5 s/d FL-13

\begin{tabular}{|c|c|c|c|c|}
\hline No. & $\begin{array}{c}\text { Mesin } \\
\text { (Proses) }\end{array}$ & Jumlah & $\begin{array}{c}\text { Waktu } \\
\text { Siklus/ } \\
\text { skid }\end{array}$ & $\begin{array}{c}\text { Kapasitas } \\
\text { Mesin Saat } \\
\text { Ini }\end{array}$ \\
\hline 1 & $\begin{array}{l}\text { Night } \\
\text { Storage }\end{array}$ & 10 & 4,6 min & $\begin{array}{c}0,46 \\
\mathrm{~min} / \mathrm{skid}\end{array}$ \\
\hline & TOTAL & & 4,6 $\min$ & $\begin{array}{c}0,46 \\
\mathrm{~min} / \text { skid }\end{array}$ \\
\hline
\end{tabular}

\section{HASIL DAN PEMBAHASAN \\ Perhitungan Takt Time ED Frame}

Angka jumlah produksi yang sudah ditentukan oleh Perusahaan sebagai perubahan Takt Time
- IMV dari 1,7 menit menjadi 1,5 menit dan

- $\quad$ EFC dari 4,8 menit menjadi 1,68 menit.

Maka Takt Time ED Frame yang dilalui oleh kedua model tersebut menjadi seperti yang ditunjukkan pada Tabel 10 dan Tabel 11.

Sesuai dengan perhitungan Takt Time yang sudah ditentukan oleh perusahaan untuk masing-masing model. Kita dapatkan Takt Time untuk lini produksi ED Frame adalah 4,6 min/skid. Selanjutnya Takt time ini akan kita jadikan sebagai target untuk pencapaian aktivitas penambahan kapasitan produksi untuk memenuhi kenaikan permintaan pelanggan.

Setelah kapasitas mesin dan target sudah diketahui, langkah selanjutnya adalah membandingkan keduanya. Gambar 4 adalah data grafik perbandingan antara kapasitas mesin dibanding dengan target.

Tabel 10. Perhitungan Takt Time ED Frame Sebelum Kenaikan Kapasitas

\begin{tabular}{cccccc}
\hline Model & $\begin{array}{c}\text { Takt Time } \\
\text { (T.T) }\end{array}$ & $\begin{array}{c}\text { Output/Jam } \\
{[60 / \text { T.T] }} \\
\text { (menit) }\end{array}$ & Unit/Skid & $\begin{array}{c}\text { Skid/Jam } \\
{[(\text { Output/Jam)/(Unit/Skid) }]}\end{array}$ & $\begin{array}{c}\text { Takt Time/Skid } \\
\text { (menit) }\end{array}$ \\
\hline IMV & 1.70 & 35.29 & 4.00 & 8.82 & \multirow{2}{*}{6.08} \\
EFC & 4.80 & 12.50 & 12.00 & 1.04 & \\
\hline \multicolumn{7}{c}{ Total } & 9.87 & \\
\hline
\end{tabular}

Tabel 11. Perhitungan Takt Time ED Frame Setelah Kenaikan Kapasitas

\begin{tabular}{cccccc}
\hline Model & $\begin{array}{c}\text { Takt Time } \\
(\text { T.T })\end{array}$ & $\begin{array}{c}\text { Output/jam } \\
\text { [60/T.T }] \\
(\text { Menit })\end{array}$ & Unit/Skid & $\begin{array}{c}\text { Skid/Jam } \\
{[(\text { Output/jam)/(Unit/skid) }]}\end{array}$ & $\begin{array}{c}\text { Takt Time/Skid } \\
\text { (Menit) }\end{array}$ \\
\hline IMV & 1.50 & 40.00 & 4.00 & 10.00 & \multirow{2}{*}{4.60} \\
EFC & 1.65 & 36.36 & 12.00 & 3.03 & \\
\hline \multicolumn{7}{c}{ Total } & & 13.03 & \\
\hline
\end{tabular}

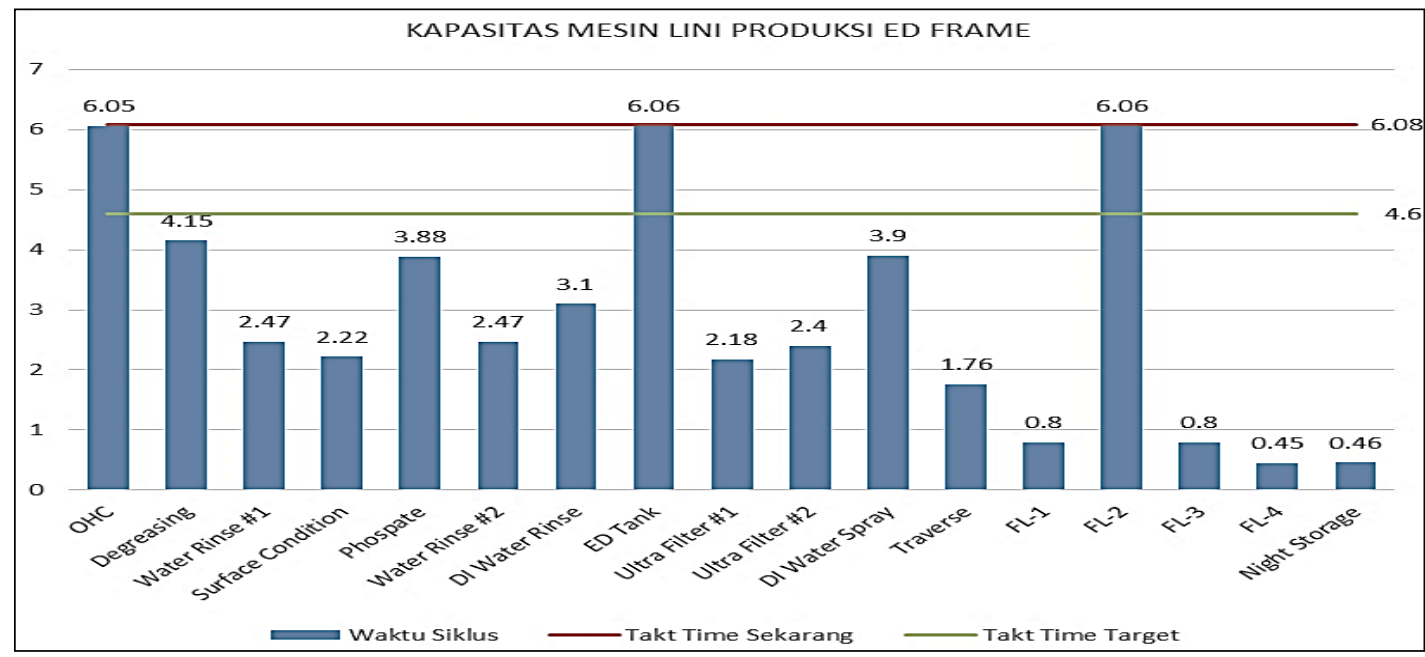

Gambar 4. Perbandingan Kapasitas Sebelum Perbaikan 
Seperti yang kita dapat dilihat berdasarkan grafik pada Gambar 4, maka dapat kita ketahui bahwa ada 3 mesin yang masih memiliki waktu siklus diatas target yang sudah ditentukan. Diantara mesin-mesin tersebut adalah OHC, ED Tank, dan FL-2 (oven).

\section{Analisis Perbaikan}

Setelah dibandingkan waktu siklus setiap mesin dengan Takt Time target. Dengan ini maka sudah diemukan dimana letak problem yang harus ditanggulangi. Langkah selanjutnya adalah menentukan perbaikan apa yang akan dilakukan untuk dapat menurunkan waktu siklus mesin yang melebihi Takt Time target menjadi sesuai dengan kapasitas yang diinginkan.

\section{OHC (Over Head Conveyor)}

Dari mesin OHC, dilakukan analisis sebab-akibat dari permasalahan kapasitas $\mathrm{OHC}$ yang belum dapat mencapai kapasitas target. Ditemukan akar penyebab dari 2 kategori yaitu dari segi mesin dan sari segi metode. Berikut analisis sebab akibat yang divisualisasikan menggunakan diagram sebab-akibat (fishbone diagram). Setelah didapatkan mengenai analisis sebab-akibat dari permasalahan yang ada. Telah didapat Perbandingan beberapa alternatif perbaikan dari hasil analisis diagram sebabakibat yakni seperti terlihat pada Tabel 12 .

Dibandingkan setiap alternatif perbaikan terhadap 3 KPI yang dianggap memiliki pengaruh besar terhadap perubahan yang ada. Maka dapat kita lihat bahwa keputusan yang diambil adalah dengan menambahkan jumlah OHC yang dimiliki. Selanjutnya perlu diketahui berapa banyak kebutuhan OHC yang harus ditambahkan untuk dapat memenuhi Tak Time target.

Jumlah OHC yang dibutuhkan:

$$
\begin{aligned}
\frac{\text { Waktu } \frac{\text { Siklus }}{\text { skid }}}{\text { Takt Time } \text { Target }} & =\frac{48,8}{4,6} \\
& =10,6 \text { unit } \sim \mathbf{1 1} \text { unit }
\end{aligned}
$$

\section{ED Tank}

Setelah dilakukan analisis sebab-akibat dari permasalahan yang ada. Didapatkan perbandingan beberapa alternatif perbaikan dari hasil analisis diagram sebab-akibat (Tabel 13).

Tabel 12. Alternatif Perbaikan OHC

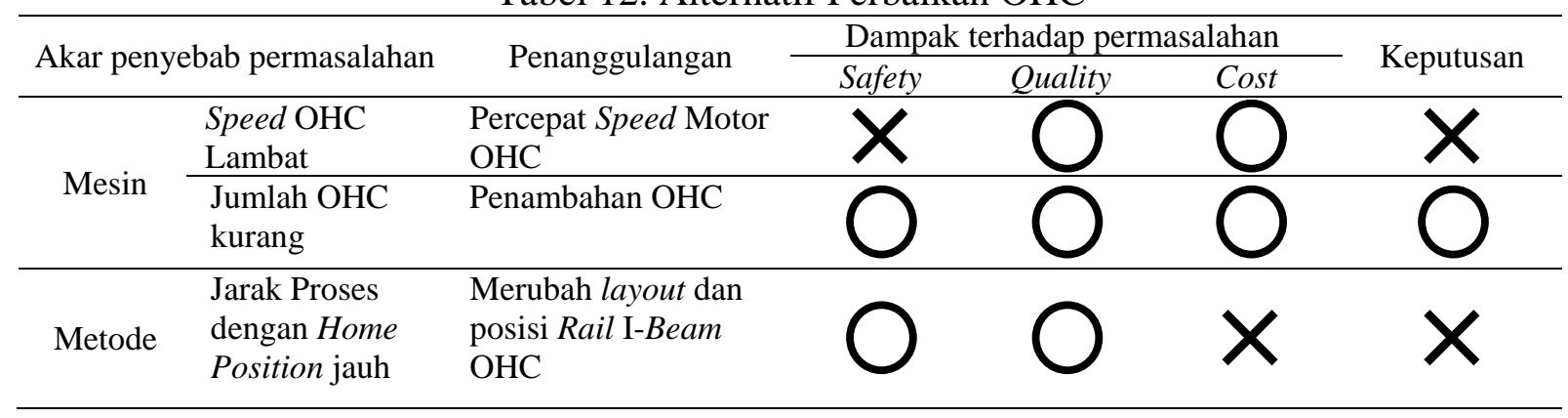

Tabel 13. Alternatif Perbaikan ED Tank

\begin{tabular}{clll}
\hline \multirow{2}{*}{ Akar Penyebab Permasalahan } & \multicolumn{2}{c}{ Penanggulangan } \\
\cline { 3 - 4 } Mesin & $\begin{array}{l}\text { Setting Waktu } \\
\text { Pencelupan Lama }\end{array}$ & $\begin{array}{l}\text { Percepat Timer } \\
\text { Dipping Time }\end{array}$ \\
\cline { 2 - 5 } & $\begin{array}{l}\text { Jumlah ED Tank } \\
\text { Hanya 1 Proses }\end{array}$ & $\begin{array}{l}\text { Fabrikasi 1 } \\
\text { Tambahan ED Tank } \\
\text { Baru }\end{array}$ \\
Metode & $\begin{array}{l}\text { Proses Clamp } \\
\text { Arde dan Hoist } \\
\text { Up-Down } \\
\text { Manual }\end{array}$ & Otomatisasi Proses
\end{tabular}


Jumlah ED Tank yang dibutuhkan:

$$
\begin{aligned}
\frac{\text { Waktu } \frac{\text { Siklus }}{\text { Skid }}}{\text { Takt Time Target }} & =\frac{6,06}{4,6} \\
& =1,32 \text { Tank } \sim 2 \text { Tank }
\end{aligned}
$$

Kebutuhan penambahan ED Tank:

Jumlah ED Tank yang dibutuhkan

$$
\begin{aligned}
& - \text { Jumlah ED Tank sekarang } \\
& =2-1=\mathbf{1} \text { ED Tank }
\end{aligned}
$$

\section{FL-2 (Oven)}

Setelah dilakukan analisis sebab-akibat dari FL-2 (oven) untuk dapat menentukan poin perbaikan yang dilakukan untuk dapat memperbaiki kapasitas FL-2, dikarenakan FL-2 ini adalah pekerjaan mesin secara otomatis sehingga diagram sebab-akibat dilihat dari segi mesin.
Perbandingan beberapa alternatif perbaikan dari hasil analisis diagram sebabakibat (Tabel 14).

Jumlah Oven Pos yang dibutuhkan:

$$
\begin{aligned}
\frac{\text { Waktu } \frac{\text { Siklus }}{\text { skid }}}{\text { Takt Time Target }} & =\frac{30,3}{4,6} \\
& =6,59 \text { Pos } \sim 7 \text { Pos }
\end{aligned}
$$

Kebutuhan penambahan Oven Pos:

Jumlah Pos yang dibutuhkan

$$
\begin{aligned}
& - \text { Jumlah Pos sekarang } \\
& =7-5=2 \text { Oven Pos }
\end{aligned}
$$

\section{Jadwal Aktivitas}

Jadwal untuk perbaikan kapasitas mesin ditunjukkan pada Tabel 15.

Tabel 14. Alternatif Perbaikan FL-2 (Oven)

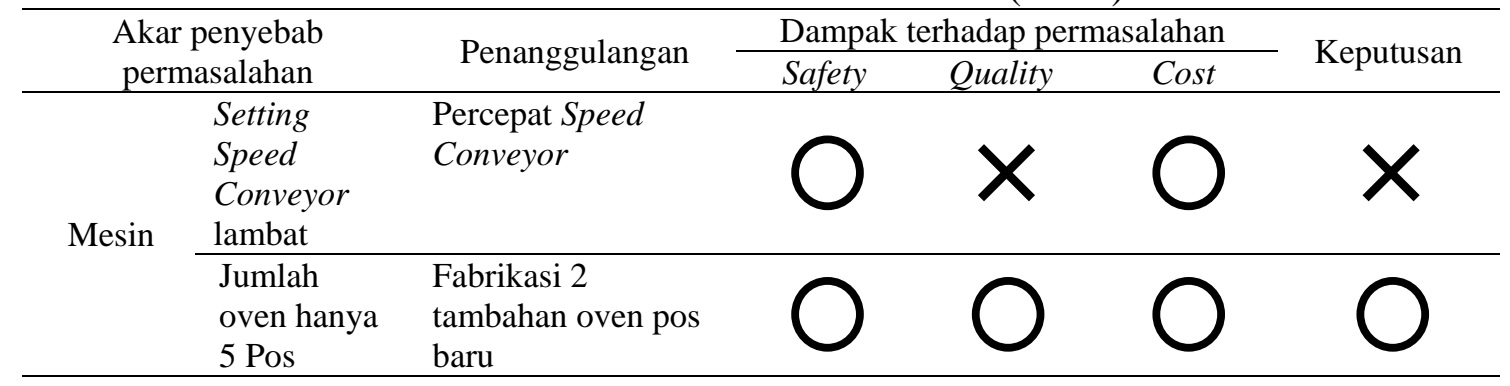

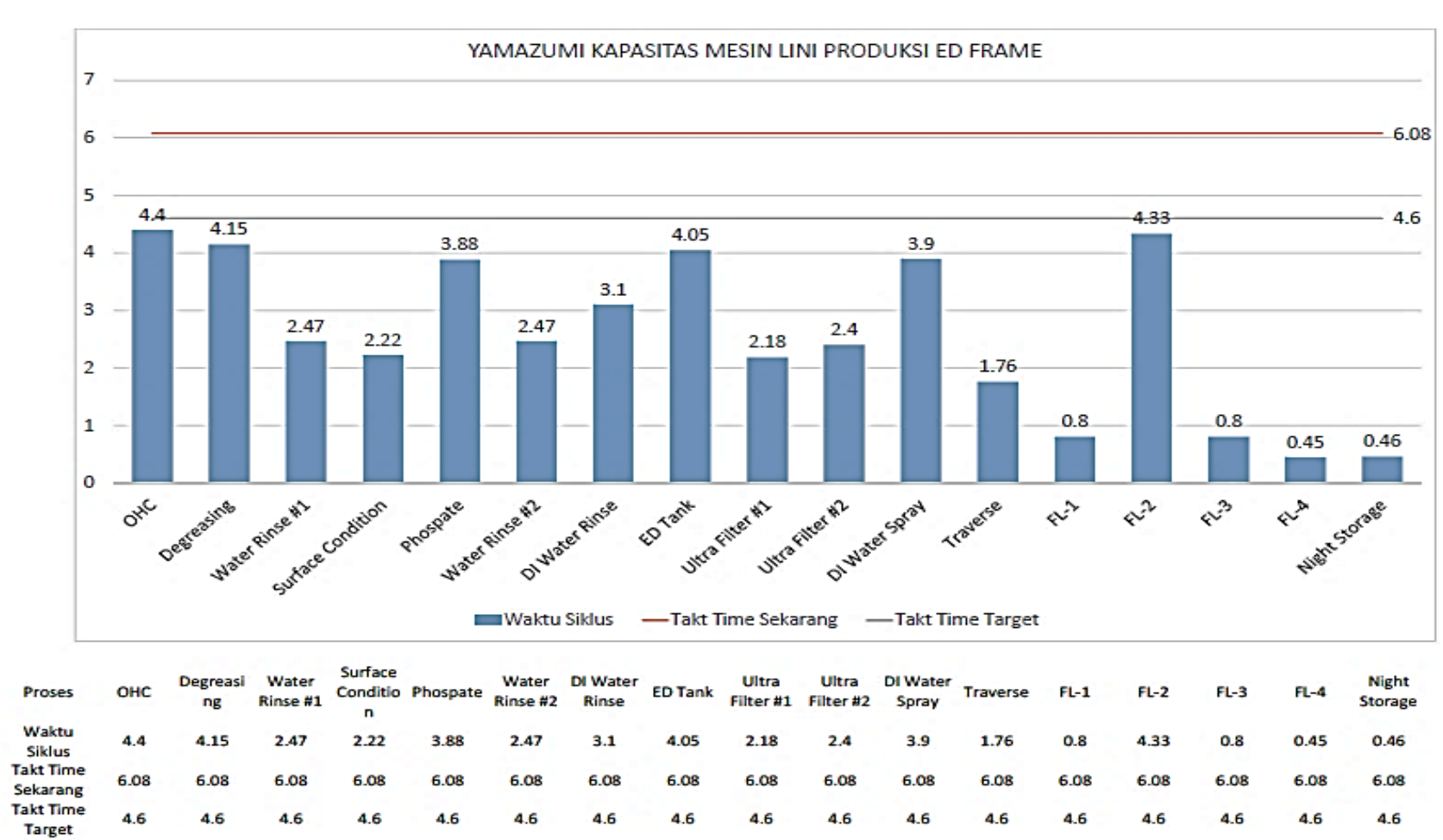

Gambar 5. Perbandingan Kapasitas Setelah Perbaikan 
Tabel 15. Jadwal Aktivitas Perbaikan Kapasitas Mesin

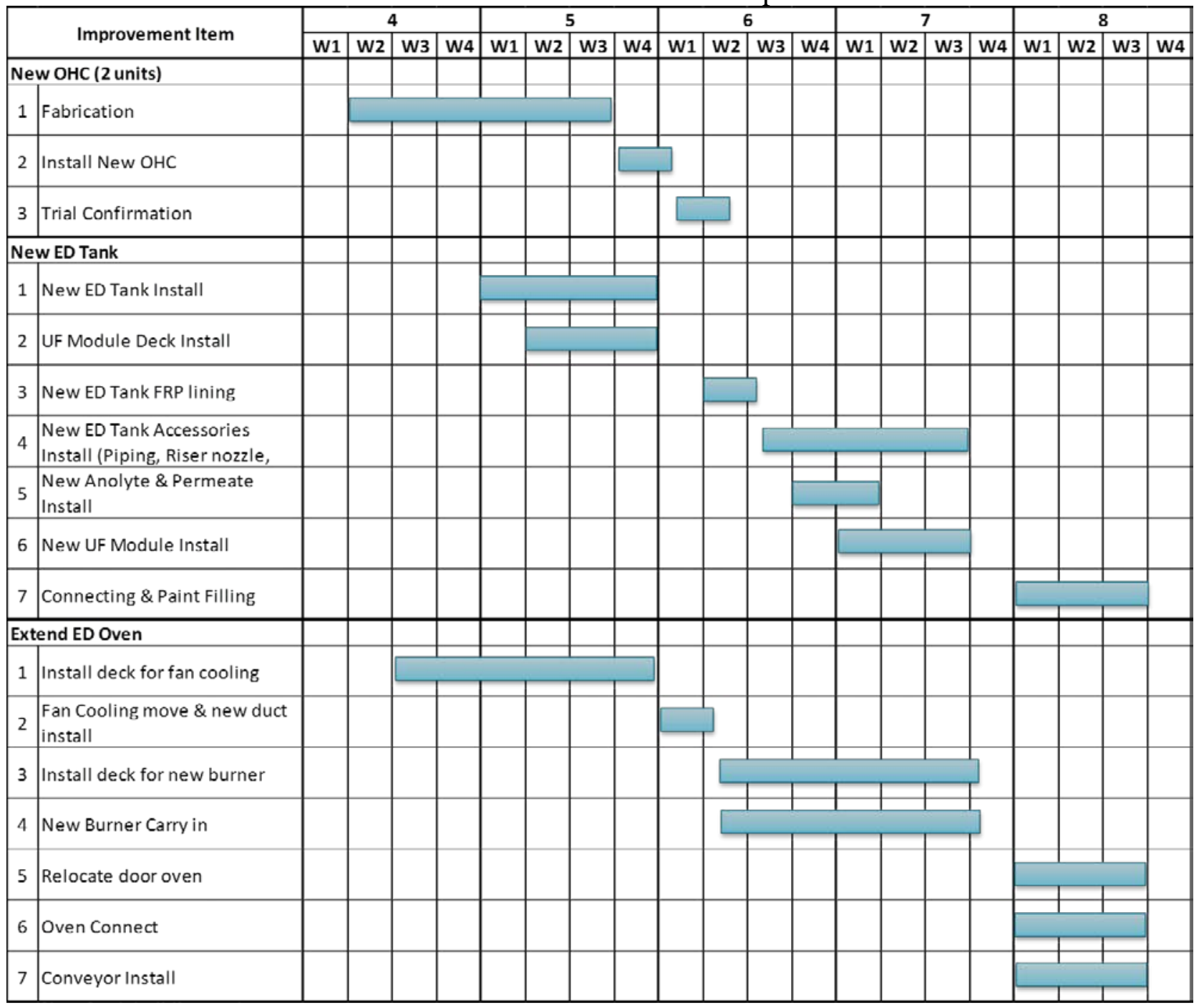

\section{Hasil Perbaikan}

Rencana perbaikan yang sudah di definisikan sebelumnya dijadwalkan dan dilakukan perbaikan sesuai dengan ketentuan yang telah ditetapkan. Selanjutnya perbaikan yang telah dilakukan di-review kembali dibandingkan dengan target kembali sehingga dapat diketahui perbaikan yang dilakukan berhasil dan sesuai target atau tidak. Hasilnya sesuai dengan target.

\section{KESIMPULAN}

Dari hasil pengumpulan dan pengolahan data yang telah dilakukan, maka dapat diambil kesimpulan bahwa setelah dilakukan penelitian dan penambahan mesin untuk dapat meningkatkan kapasitas, Cycle Time proses dari keseluruhan mesin yang ada pada lini produksi ED Frame menurun dan dapat memenuhi Takt
Time yang telah ditentukan oleh Top Management terkait dengan meningkatnya permintaan yang menuntut kenaikan kapasitas produksi.

\section{DAFTAR PUSTAKA}

[1]. Grover, Mikell P., 2001, Automation, Production Systems, and computer integrated Manufacturing, $2^{\text {nd }}$ edition, New Jersey: Prentice-Hall, Inc.

[2]. Jay Heizer dan Barry Render, 2014, Manajemen Operasi: Edisi kesembilan, Penerbit Salemba Empat, Jakarta.

[3]. Isao Kato dan Art Smalley, 2014, Toyota Kaizen Methods 6 Langkah Perbaikan, Gradien Mediatama, Yogyakarta.

[4]. Andika, 2014, Seven Tools of Quality, Universitas Mercu Buana, Jakarta. 